Дмитрук Зоя Анатоліївна, здобувач $\mathrm{PhD}$ у галузі знань: «01Освіта/Педагогіка» аспірант кафедри педагогіки, адміністрування та спеціальної освіти ДЗВО «Університет менеджменту освіти», завідувач сектору позашкільної освіти, виховної роботи та молодіжної політики Департаменту освіти і науки Одеської обласної державної адміністрації, вул. Базарна, 83, м. Одеса, 65107, тел.: (048) 722-52-54, e-mail: departament_dmitruk@ukr.net, https://orcid.org/0000-0003-4279-2838

\title{
РЕЗУЛЬТАТИВНІСТЬ ВПРОВАДЖЕННЯ МОДЕЛІ УПРАВЛІННЯ ПРОЦЕСОМ ПОЗИЦІОНУВАННЯ ЗАКЛАДУ ЗАГАЛЬНОЇ СЕРЕДНЬОЇ ОСВІТИ НА РЕГІОНАЛЬНОМУ РИНКУ ОСВІТНІХ ПОСЛУГ НА ОСНОВІ НАЦІОНАЛЬНО-ПАТРІОТИЧНИХ ЦІННОСТЕЙ
}

Анотація. Сфера освіти сьогодні переживає процесс модернізації, глибоких соціальних, духовних та економічних зрушень. Управлінська теорія та практика постійно набуває нових форм, методів та засобів щодо реалізації основних завдань. Поряд з цим, перед закладом загальної середньої освіти як відкритої соціально-педагогічної системи, що формує особистість - патріота України, постають вагомі виклики в ринкових умовах функціонування.

У нашому дисертаційному дослідженні актуалізовано питання управління процессом позиціонування закладу загальної середньої освіти на регіональному ринку освітніх послуг на основі національно-патріотичних цінностей та представлено в даній статті основні результати впровадження авторської моделі управління процессом позиціонування закладу загальної середньої освіти.

Експериментальною базою для реалізації авторського освітнього проєкту «Партнерство як ресурс» як основного інструменту експериментальної частини нашого дослідження, стали заклади загальної середньої освіти територіальних громад Одеської області, зокрема, Южненської міської територіальної громади Одеського району Одеської області, Арцизької міської територіальної громади Болградського району Одеської області, Тарутинської селищної ради Болградського району Одеської області та Розквітівської сільської територіальної громади Одеської області.

Аналіз результативності впровадження моделі управління процесом позиціонування закладу загальної середньої освіти на регіональному ринку освітніх послуг на основі національно-патріотичних цінностей, який здійснено відповідно до факторно-критеріальної моделі нашого дослідження показав, що управління взаємопов'язаними факторами приводить до зростання не лише 
компонентів управління, на які безпосередньо спрямовується управлінський вплив, але й дотичних до них факторів. Це пояснюється тим, що усі визначені нами фактори процесу позиціонування закладу загальної середньої освіти $\epsilon$ взаємоповязаними та взаємозалежними між собою.

Зазначено, що відповідно до результатів дослідження, формування сильної дієвої позиції процесу позиціонування закладу загальної середньої освіти на регіональному ринку освітніх послуг на основі національно-патріотичних цінностей стає вагомим сучасним ефективним ресурсом з громадою та у розвитку конкурентоспроможності закладу освіти.

Ключові слова: позиціонування, національно-патріотичні цінності, курінь, фактори та критерії процесу позиціонування, заклад загальної середньої освіти.

Dmytruk Zoia Anatolievna $\mathrm{PhD}$ applicant in the field of knowledge: "01Education / Pedagogy" graduate student of the Department of Pedagogy, Administration and Special Education DZVO "University of Education Management", Head of the sector of extracurricular education, educational work and youth policy of the Department of Education and Science of the Odessa Regional State Administration, st. Bazarna, 83, Odessa, 65107, tel $\therefore$ (048) 722-52-54, e-mail: departament_dmitruk@ukr.net, https://orcid.org/0000-0003-4279-2838

\section{EFFECTIVENESS OF IMPLEMENTATION OF THE POSITIONING PROCESS MANAGEMENT MODEL GENERAL SECONDARY EDUCATION INSTITUTIONS IN THE REGIONAL MARKET OF EDUCATIONAL SERVICES ON THE BASIS OF NATIONAL-PATRIOTIC VALUES}

Abstract. The field of education today is undergoing a process of modernization, profound social, spiritual and economic changes. Management theory and practice is constantly acquiring new forms, methods and tools for the implementation of basic tasks. Along with this, the institution of general secondary education as an open sociopedagogical system that shapes the personality - a patriot of Ukraine, faces significant challenges in the market conditions of operation.

In our dissertation research the issue of managing the process of positioning a general secondary education institution in the regional market of educational services on the basis of national-patriotic values is actualized and the main results of implementing the author's model of managing the process of positioning a secondary school are presented.

The experimental base for the implementation of the author's educational project "Partnership as a resource" as the main tool of the experimental part of our study were general secondary education institutions of territorial communities of Odessa region, in particular, Yuzhne city territorial community of Odessa district of Odessa region, Artsyz city territorial community of Bolgrad district of Odessa region, Tarutyn village 
council of Bolgrad district of Odessa region and Rozkvitivka village territorial community of Odessa region.

Analysis of the effectiveness of the management model of the process of positioning general secondary education in the regional market of educational services based on national-patriotic values, which is carried out in accordance with the factorcriterion model of our study showed that management of interrelated factors leads to growth not only which directly directs the managerial influence, but also the factors related to them. This is due to the fact that all the factors identified by us in the process of positioning the institution of general secondary education are interconnected and interdependent.

It is noted that according to the results of the study, the formation of a strong effective position in the positioning of general secondary education in the regional market of educational services based on national and patriotic values becomes a significant modern effective resource in community interaction and competitiveness.

Key words: positioning, national-patriotic values, hut, factors and criteria of the positioning process, general secondary education institution.

Постановка проблеми. Основою еспериментальної частини нашого дослідження $\epsilon$ авторський освітній проєкт «Партнерство як ресурс», просвітницьку частину якого було адресовано закладам загальної середньої освіти Одеської області, зокрема, результати дослідження впроваджено у систему управління таких закладів: комунального закладу «Новобілярська гімназія» Южненської міської ради Одеського району Одеської області, Виноградівського опорного закладу загальної середньої освіти Арцизької міської ради Болградського району Одеської області, Тарутинський навчально-виховний комплекс “Загальноосвітня школа I-III ступенів - ліцей - дошкільний навчальний заклад” Тарутинської селищної ради Болградського району Одеської області, Розквітівської загальноосвітньої школи I-III ступенів Розквітівської сільської ради Березівського району Одеської області та інших.

Досліджуючи результативність управління процесом позиціонування закладу загальної середньої освіти на основі національно-патріотичних цінностей, оцінювали окремі елементи зазначеного процесу (фактори): фінансову та матеріально-технічну забезпеченість, мотиваційно-ціннісний, інформаційноіміджевий, компетентнісний та управлінський (відповідно до факторнокритеріальної моделі нашого дослідження).

Однією з сильних ціннісних позицій процесу позиціонування закладу загальної середньої освіти на регіональному ринку освітніх послуг постає курінь - осередок, сформований на принципах самоврядності та який $є$ базовою організаційною одиницею Всеукраїнської дитячо-юнацької військово-патріотичної гри «Сокіл» («Джура») [6]. 
Інструментами впровадження та перевірки нашої наукової гіпотези, яка полягає в твердженні, що сильна дієва позиція закладу загальної середньої освіти, побудована на національно-патріотичних цінностях, сприятиме підвищенню ефективності процесу позиціонування та його розвитку загалом, стала Одеська обласна школа виховників джур (сформована як система заходів) з методичним підгрунттям - освітньою регіональною програмою організації та проведення підвищення кваліфікації фахівців 3 національно-патріотичного виховання (педагогічних працівників, громадських діячів, волонтерів) [5].

Слід зауважити, аналіз результативності впровадження моделі управління процесом позиціонування на регіональному ринку освітніх послуг на основі національно-патріотичних цінностей не тільки свідчить про підтвердження нашої наукової гіпотези, яку викладено вище, але й показав, що управління взаємопов'язаними факторами приводить до зростання не лише компонентів управління, на які безпосередньо спрямовується управлінський вплив, але й дотичних до них факторів. Це пояснюється тим, що усі визначені нами фактори процесу позиціонування закладу загальної середньої освіти є взаємоповязаними та взаємозалежними між собою.

Таким чином, за результатами нашого дослідження можна стверджувати, що управлінська проблема позиціонування закладу загальної середньої освіти на регіональному ринку освітніх послуг на основі національно-патріотичних цінностей $€$ перспективним напрямом наукової діяльності та потребує подальшого вивчення, дослідження і розвитку.

Аналіз останніх досліджень і публікацій. Аналіз досліджень свідчить, що питанням оцінювання ефективності процессу позиціонування присвячені праці таких дослідників як У. Уеллса, Ж.-Ж. Ламбена, Л. Персі, Р. Ривса, Д. Аакера та інших.

В останні роки метод кваліметрії в педагогічній діагностиці в Україні активно впроваджують О.Ануфрієва, Г.Дмитренко, Г.Сльникова, Т. Махиня [1;2;3;4].

Мета статті - здійснення аналізу результативності основних аспектів впровадження моделі управління процесом позиціонування закладу загальної середньої освіти на регіональному ринку освітніх послуг на основі національнопатріотичних цінностей.

Виклад основного матеріалу. В нашій аналітичній діяльності виходимо за межі традиційного порівняння отриманих результатів та еталонних показників. Аналіз здійснено, в тому числі, для виявлення причин відхилень результатів контролю стану об’єкта управління від запланованих або попередніх результатів, a також для виявлення сильних i слабких сторін функціонування об'єкта управління $з$ метою корекції його подальшого розвитку.

У процесі діагностування отримуємо інформацію, заміри відбувались постійно, інформація накопичувалась за певні проміжки часу. Інформацію нами проаналізовано, динаміка критеріїв - вивчена, систематизована, критично оцінена, проіндексована та узагальнена у вигляді результатів дослідження 
об'єкта управління, інтерпретована. Після аналізу та інтерпретації результатів сформовано висновки та надано методичні рекомендації щодо впровадження моделі управління процесом позиціонування закладу загальної середньої освіти на регіональному ринку освітніх послуг на основі національно-патріотичних цінностей.

Як зазначалось вище нами було утворено факторно-критеріальну модель, в якій такі фактори: фінансова та матеріально-технічна забезпеченість, мотиваційно-ціннісний, інформаційно-іміджевий, компетентнісний та управлінський, кожен розкрито за допомогою відповідних критеріїв.

Факторно-креторіальна модель управління процесом позиціонування закладу загальної середньої освіти на регіональному ринку освітніх послуг на основі національно-патрілотичних цінностей включає такі складові: "вагомість параметрів" (M), "вагомість факторів (m)" та "вагомість критеріїв (v)", значення яких виводиться за методом Дельфі на підставі проведених замірів пріоритетності певних аспектів процесу позиціонування.

Результативність процесу позиціонування встановлюється на основі сумарного кінцевого показника кожного елементу зазначеного процесу.

Усього в експериментальній перевірці взяли участь 2574 осіб, 3 них керівників 33СО - 59, педагогічних працівників - 570, учнів - 1920, представників громадськості - 25.

За результатами впровадження моделі управління процесом позиціонування закладу загальної середньої освіти на регіональному ринку освітніх послуг в Одеській області утворено та функціонують 57 куренів як осередків 3 національно-патріотичного виховання учнівської молоді - базових організаційних одиниць Всеукраїнської дитячо-юнацької військово-патріотичної гри «Сокіл» («Джура»). Зазначені сильні дієві позиції закладів загальної середньої освіти на основі національно-патріотичних цінностей утворено у Березівському районі Одеської області (4), Болградському районі Одеської області (3), Ізмаїльському районі Одеської області (9), в Одеському районі Одеської області (23), Подільському районі Одеської області (11), Роздільнянському районі Одеської області (7).

Діяльність куреня спрямовано на індивідуальний розвиток особистості учня та його самореалізацію шляхом залучення в колективних заходах та діях.

Виховні методи діяльності куреня передбачають набуття громадянських компетентностей у трьох вікових групах: молоді козаки - найстарша організаційно-виховна вікова група; джури - середня (основна) вікова група; новаки (козачата) - початкова вікова група Всеукраїнської дитячо-юнацької військово-патріотичної гри «Сокіл» («Джура») [7].

Курінь може складатися з одного або двох роїв молодих козаків, від трьох до п’яти роїв джур і у разі потреби/можливості - двох або трьох роїв новаків (козачат). Кожен курінь обирає собі назву за іменем покровителя (патрона) - 
історичної постаті місцевого або загальнонаціонального значення, яка відзначилася вагомим внеском у боротьбу за державність України в період від часів княжої доби до революції Гідності та під час захисту України від збройної агресії Російської Федерації в антитерористичній операції, операції Об'єднаних сил в Донецькій та Луганській областях (наприклад, курінь імені Миколи Руденка, який сформовано на базі комунального закладу «Новобілярська гімназія» Южненської міської ради Одеського району Одеської області).

Відповідно до пункту 14 Положення про Всеукраїнську дитячо-юнацьку військово-патріотичну гру «Сокіл» («Джура»), затвердженого Постановою Кабінету міністрів України від 17.10.2018 № 845 «Деякі питання дитячоюнацького військово-патріотичного виховання» курені згаданої гри реєструються Головним штабом гри або за його дорученням - обласним штабом. Порядок реєстрації куренів Всеукраїнської дитячо-юнацької військово-патріотичної гри «Сокіл» («Джура») затверджено наказом Українського державного центру національно-патріотичного виховання, краєзнавства і туризму учнівської молоді від 02 квітня №29-А «Про порядок реєстрації куренів Всеукраїнської дитячоюнацької військово-патріотичної гри «Сокіл» («Джура»)».

Основними видами діяльності куреня впродовж навчального року є:

- вишколи ройових та їх заступників;

- рада ройових;

- ройовий змаг;

- щотижневі сходини куреня;

- мандрівки;

- змагання;

- таборування тощо.

Крім того, кожен рій веде свою Книгу звитяг, яка складається 3 двох частин: «Спадок» та «Здобуток». У спадок збираються, в тому числі, усні, архівні свідчення про боротьбу за державну незалежність України в районі (місті, селі), а в «Здобутки» вписуються свої перемоги, досягнення, імена козачат, джур, молодих козаків куреня тощо.

Кожен курінь веде свою сторінку (блог) в мережі Інтернет та викладає світлини та відеоматеріали, пов'язані з його діяльністю.

Підсумком діяльності куреня протягом навчального року $\epsilon$ наметове таборування, яке організовує виховник та рада ройових за сприяння адміністрації закладу освіти та місцевого органу управління освіти.

На прикладі Южненської міської територіальної громади Одеського району Одеської області зазначимо про результативність впровадження моделі управління процесом позиціонування закладу загальної середньої освіти на регіональному ринку освітніх послуг на основі національно-патріотичних цінностей. У зазначеній громаді утворено курені у всіх закладах загальної середньої освіти, а саме 6 куренів (таблиця 1). 
Таблиия 1.

\begin{tabular}{|c|c|c|}
\hline 1 & $\begin{array}{l}\text { Комунальний заклад «Южненська Авторська } \\
\text { М.П.Гузика експериментальна спеціалізована } \\
\text { загальноосвітня школа-комплекс I-III ступенів } \\
\text { Южненської міської ради Одеської області» }\end{array}$ & Курінь ім. Миколи Міхновського \\
\hline 2 & $\begin{array}{l}\text { Комунальний заклад «Южненська } \\
\text { загальноосвітня школа І-ІІІ ступенів № } 1 \\
\text { Южненської міської ради Одеської області» }\end{array}$ & Курінь ім. Сергія Кемського \\
\hline 3 & $\begin{array}{l}\text { Комунальний заклад «Южненський навчально- } \\
\text { виховний комплекс імені В’ячеслава Чорновола } \\
\text { (гімназія - загальноосвітня школа І ступеня ) } \\
\text { Южненської міської ради Одеської області» }\end{array}$ & Курінь ім. Івана Липи \\
\hline 4 & $\begin{array}{l}\text { Комунальний заклад «Южненський навчально- } \\
\text { виховний комплекс (загальноосвітня спеціалізована } \\
\text { школа І-ІІІ ступенів №2 - центр позашкільної освіти } \\
\text { - професійно-технічне училище) Южненської } \\
\text { міської ради Одеської області» }\end{array}$ & Курінь ім. Петра Франка \\
\hline 5 & $\begin{array}{l}\text { Комунальний заклад «Новобілярська гімназія» } \\
\text { Южненської міської ради Одеського району } \\
\text { Одеської області }\end{array}$ & Курінь ім. Миколи Руденка \\
\hline 6 & $\begin{array}{l}\text { Сичавська загальноосвітня школа I-III ступенів } \\
\text { Лиманської районної ради Одеської області }\end{array}$ & Курінь ім. Івана Мірного \\
\hline
\end{tabular}

Аналіз результатів впровадження моделі управління процесом позиціонування закладу загальної середньої освіти на регіональному ринку освітніх послуг у зазначених вище закладах освіти Южненської міської територіальної громади підтверджує позитивну динаміку критеріїв процесу позиціонування на основі національно-патріотичних цінностей визначених у дослідженні, що відображено у діаграмі. За відповідними розрахунками з'ясовано, що середнє арифметичне загального приросту індексної оцінки складає 0,13 (13\%).

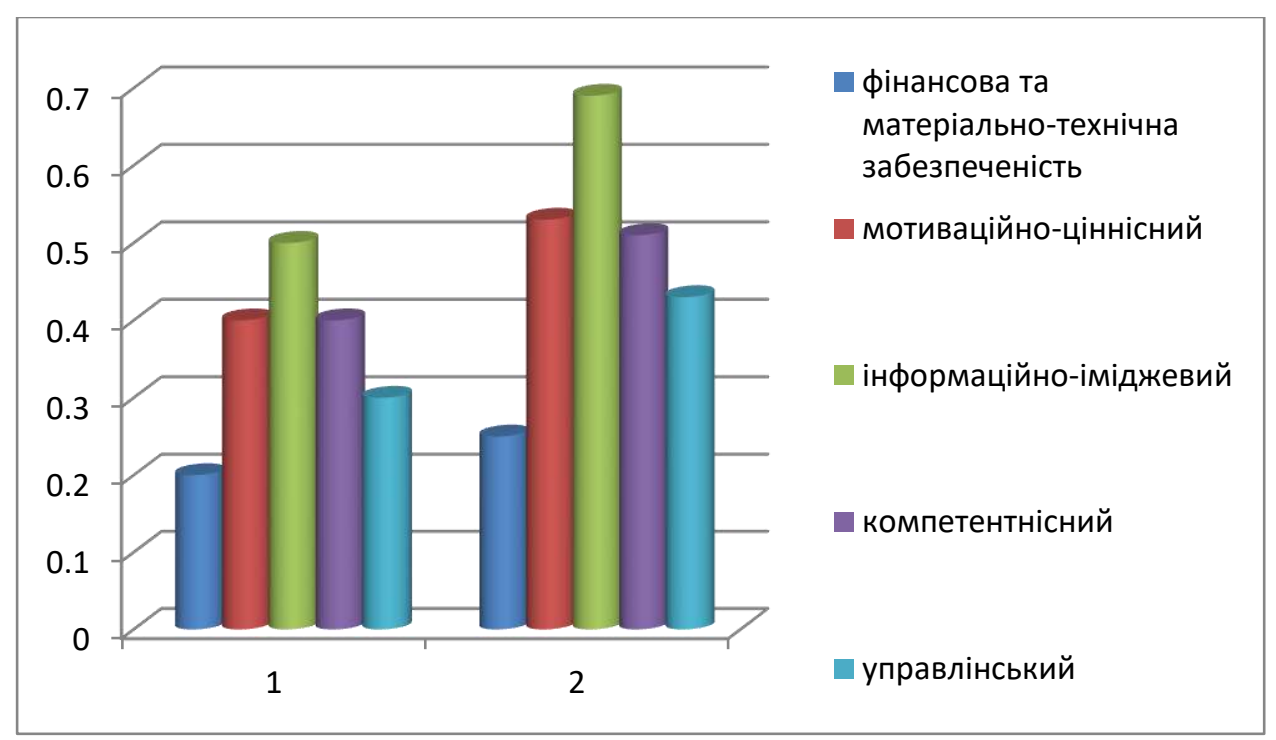


Діаграма приросту індексних оцінок за критеріями процесу позиціонування закладу загальної середньої освіти на регіональному ринку освітніх послуг на основі національно-патріотичних цінностей.

Крім того, аналіз результативності впровадження моделі управління процесом позиціонування закладу загальної середньої освіти на регіональному ринку освітніх послуг на основі національно-патріотичних цінностей, який здійснено відповідно до факторно-критеріальної моделі нашого дослідження показав, що управління взаємопов'язаними факторами приводить до зростання не лише компонентів управління, на які безпосередньо спрямовується управлінський вплив, але й дотичних до них факторів. Це пояснюється тим, що усі визначені нами фактори процесу позиціонування закладу загальної середньої освіти є взаємоповязаними та взаємозалежними між собою.

Висновки. Аналіз результативності основних аспектів впровадження моделі управління процесом позиціонування закладу загальної середньої освіти на регіональному ринку освітніх послуг на основі національно-патріотичних цінностей дає можливість стверджувати про іiї ефективність щодо підвищення рівня позиціонування. Курені як осередки 3 національно-патріотичного виховання учнівської молоді стають сильною діючою унікальною позицією процесу позиціонування закладу загальної середньої освіти. Але управлінська проблема позиціонування закладу загальної середньої освіти на регіональному ринку освітніх послуг, зокрема, на основі емоційних (національно-патріотичних) цінностей недостатньо висвітлена у науковій теорії, практиці та потребує подальшого вивчення, дослідження та розвитку.

\section{Лimepamypa:}

1. Ануфрісва О. Л. Оцінка якості початкової освіти на основі кваліметричного підходу: автореф. дис. на здобуття наук. ступ. канд. пед. наук: 13.00.01 «Загальна педагогіка та історія педагогіки» / О. Л. Ануфрієва. - К. , 2000. - 18 с.

2. Дмитренко Г. А. Стратегічний менеджмент: цільове управління освітою на основі кваліметричного підходу / Г. А. Дмитренко. - К. : ІЗМН, 1996. - 140 с.

3. Єльникова Г. В. Наукові основи розвитку управління загальною середньою освітою в регіоні : монографія / Г. В. Єльникова. - К. : ДАККО, 1999. - 303 с.

4. Махиня Т.А. Особливості реалізації принципів кваліметрії на прикладі моделі оцінювання управлінських умінь керівників дошкільних навчальних закладів https://cutt.ly/gR7ljY3

5. Освітня регіональна програма організації та проведення підвищення кваліфікації фахівців з національно-патріотичного виховання (педагогічних працівників, громадських діячів, волонтерів)/упорядник Дмитрук 3.A. https://cutt.ly/0kWImNf

6. Постанова Кабінету Міністрів України від 17 жовтня 2018 року № 845 Всеукраїнська дитячо-юнацька військово-патріотична гра "Сокіл" ("Джура") із змінами і доповненнями, внесеними постановою КМУ від 13 травня 2020 року № 367 URL: http://search.ligazakon.ua/ 1_doc2.nsf/link1/KP180845.html

7. Постанова Кабінету Міністрів України від 17 жовтня 2018 р. № 845 https://zakon.rada.gov.ua/laws/show/845-2018-\%D0\%BF\#Text 


\section{References:}

1. Anufriieva O. L. (2000) Otsinka yakosti pochatkovoi osvity na osnovi kvalimetrychnoho pidkhodu: avtoref. dys. na zdobuttia nauk. stup. kand. ped. nauk: 13.00.01 «Zahalna pedahohika ta istoriia pedahohiky», 18 [in Ukrainian].

2. Dmytrenko H. A. (1996) Stratehichnyi menedzhment: tsilove upravlinnia osvitoiu na osnovi kvalimetrychnoho pidkhodu / 140 [in Ukrainian].

3. Yelnykova H. V. (1999) Naukovi osnovy rozvytku upravlinnia zahalnoiu serednoiu osvitoiu v rehioni : monohrafiia / 303 [in Ukrainian].

4. Makhynia T.A. Osoblyvosti realizatsii pryntsypiv kvalimetrii na prykladi modeli otsiniuvannia upravlinskykh umin kerivnykiv doshkilnykh navchalnykh zakladiv https://cutt.ly/gR7ljY3

5. Osvitnia rehionalna prohrama orhanizatsii ta provedennia pidvyshchennia kvalifikatsii fakhivtsiv z natsionalno-patriotychnoho vykhovannia (pedahohichnykh pratsivnykiv, hromadskykh diiachiv, volonteriv)/uporiadnyk Dmytruk Z.A. https://cutt.ly/0kWImNf

6. Postanova Kabinetu Ministriv Ukrainy vid 17 zhovtnia 2018 roku № 845 Vseukrainska dytiacho-yunatska viiskovo-patriotychna hra "Sokil" ("Dzhura") iz zminamy i dopovnenniamy, vnesenymy postanovoiu KMU vid 13 travnia 2020 roku № 367 URL: http://search.ligazakon.ua/ 1_doc2.nsf/link1/KP180845.html

7. Postanova Kabinetu Ministriv Ukrainy vid 17 zhovtnia 2018 r. № 845 https://zakon.rada.gov.ua/laws/show/845-2018-\%D0\%BF\#Text 